\section{Review of the Book "The desire for a fair budget balance", author Ionel Bostan, C.H. Beck Publishing House, 2021}

\author{
Alunica MORARIU ${ }^{1}$ \\ ${ }^{1}$ Assoc. Professor PhD, "Stefan cel \\ Mare" University of Suceava, Romania, \\ Faculty of Economics and Public \\ Administration, \\ alunica.morariu@gmail.com
}

\begin{abstract}
The devastation of state economies as a result of the manifestation of the health crisis (COVID-19) is a certainty. The true size is likely to be known in the future, but in order to prevent a "total downturn", derogations from the fiscal-budgetary constraints imposed by the Stability and Growth Pact (the corrective arm) have been granted at EU level. However, budgetary balances are being severely affected, with an obvious increase in public debt. These transitional derogations (their necessity and justification deriving only from reasons to combat the consequences of the health crisis), make the desire for a fair budget balance to be a perpetual one, needing to be taken into account, both in critical circumstances, of any kind, as well as in periods of economic growth. Explanations and arguments can be found in the work "The desire for a fair budget balance", author Ionel Bostan, C.H. Beck Publishing House, 2021, on which we stop by this approach.
\end{abstract}

Keywords: public debt, $N A F A$, degree of collection, fiscal control/inspection, tax evasion/fraud.

How to cite: Morariu, A. (2021). Review of the Book "The desire for a fair budget balance", author Ionel Bostan, C.H. Beck Publishing House, 2021. Logos UniversalityMentality Education Novelty: Economicsand Administrative Sciences, 6(1), 7377. https://doi.org/10.18662/lumeneas/6.1/31 
Review of the Book "The desire for a fair budget balance", author Ionel Bostan... Alunica MORARIU

Against the background of the economic debates related to the new situation of deep crisis, with its multiple facets - financial, pandemic, energy and, more recently, security, the issue of balancing public budgets is a very challenging one for today's researchers. Prior to the health crisis (2019), in Romania, the budget deficit reached $4.6 \%$ of GDP in cash terms $(4.4 \%$ in terms of ESA / European System of Accounts), even if the requirement of the European Union (Protocol No. 12 on the applicable procedure excessive deficit / annex to the TFEU) is that the budget deficit, calculated according to the ESA methodology, should not exceed 3\% of GDP.

Before the official declaration of the health crisis, the European Commission recommended to Romania, within the Excessive Deficit Procedure, to return by 2022 to a deficit of less than 3\%. The reasons for the need to combat the effects of the COVID-19 pandemic - which generated even greater deficits - led to an exceptional measure: on 20 March 2020, the European Commission, with the agreement of the European Council, came with a derogation from the restrictions imposed by the Stability and Growth (the corrective arm), adopting the "general derogation clause", valid at both European and national level (for all Member States within a state of widespread crisis). This allowed for temporary and orderly deviations from the existing tax regime.

However, the above situation cannot but have consequences for public debt as well. If we talk about Romania, we must take into account what the academician Daniel Daianu recently said: "The public debt has already reached the threshold of about 50 percent of GDP. It is essential that, in the years to come, this debt, even if it continues to grow, stabilize (public finances be sustainable), and this goal depends essentially on budgetary consolidation - which, in turn, depends on a firm step average annual adjustment of the budget deficit of 1.5 percent of GDP (a cumulative deficit reduction of about 6 percent of GDP) in the period 2021-2024. It is worth mentioning that Romania is under the Excessive Deficit Procedure, even if the rules will be reactivated only from 2023".

Professor Ionel Bostan notices in this regard a whole series of reasons that determine the well-founded approach meant to motivate the control of imbalances.

The consolidation of the budget, the prevention of the weakening of the sustainability of public finances, the permanent control of the state authorities in terms of government revenues and expenditures, must be manifested permanently, regardless of the economic situation. In this sense, the author, alone or in groups of researchers, has dealt with a whole series of such topics, which have been published over time (Bostan, 2010a, 2010b, 
2014; Bostan \& Grosu, 2009; Bostan \& Radu, 2003; Bostan et al., 2013; Grosu \& Bostan, 2010; Onofrei et al., 2021; Tinică et al., 2013), and which are of real interest.

Recently, however, Professor Ionel Bostan published the paper The Desire for Fair Budget Balance, published by $\mathrm{CH}$ Beck Publishing House, Bucharest, 2021 (pages: 190). The content of the book is given, in fact, by a series of articles published by the author in the economic and business press between September 2019 and September 2021.

Among them, the ones that are directly useful and important are the ones that focus directly on the budgetary issue of the stage we are going through, such as: Reconfiguring the EU pandemic budget, Budgetary policy, between the excessive deficit procedure and the general derogation clause, Current budget (dis)proportions, Government debt or Pseudo-budgetary savings by accepting the cheapest price. In correlation with these, the author makes two syntheses, which support the reader, facilitating his full understanding of the issue of budget balance by connecting to the data of the real economy. These summaries, positioned towards the end of the book, refer to: (i) the budgetary effort (2021) to eliminate the effects of the pandemic crisis and (ii) the public debt and the financing of the budget deficit.

The author wants to emphasize, with reference to Romania, that "The undesirable situation of exceeding $60 \%$ of the share of public debt in GDP (the critical threshold stipulated in the Maastricht Treaty) would automatically attract - without legal problems - the measure of freezing wage expenditures from the public sector and those with social assistance. The increase in public debt by more than $12 \%$, as a share of GDP, in a single year, cannot but worry those concerned about the sustainability of state finances in the medium term. It is true that the year in question is 2020, the year which was most economically affected by the COVID-19 pandemic, forcing upward budget spending through three rounds of corrections" (Bostan, 2021).

In the sections of the paper we also find references to financial control, addressing attempts to relegate the external public audit, some actual results of the activity of the General Directorate of Fiscal Anti-Fraud recently, including the performance of fiscal (tele)control (during the pandemic).

Other sub-topics included in the mentioned paper: New coordinates for exercising the administrative-fiscal jurisdiction, How much and in which way the Tax Office (ANAF) is enforced in special cases, The fiscal space in variable contour. We find it extremely interesting that the approach is related to the sub-theme "Romania 2021: sustainable economic growth or simple post-crisis 
Review of the Book "The desire for a fair budget balance", author Ionel Bostan...

recovery?" or the one on "Flexibility of the implementation of major investment projects".

However, the author warns readers that the derogation from the restrictions imposed by the Stability and Growth Pact (the corrective arm) is only of a transitional nature, not exceeding 2024, the need and justification deriving only from reasons to combat the consequences of the health crisis (COVID-19).

Therefore, the desire for a fair budget balance is perpetual, needing to be taken into account, both in critical circumstances, of whatever nature, and in periods of economic growth.

\section{References}

Bostan, I. (2010a). Performance of financial control. Theoretical and Applied Economics, 7(7), 77. http://store.ectap.ro/articole/485.pdf

Bostan, I. (2010b). Auditul public extern [External public audit]. Universul Juridic SRL.

Bostan, I. (2014). Juridical tools of Governmental nature used to mitigate various difficulties of the Financial and Budgetary System. Annals of the Alexandru Ioan Cura University-Economics, 61(2), 133-148. http://saaic.feaa.uaic.ro/index.php/saaic/article/view/184

Bostan, I. (2021). Dezideratul justului echilibru bugetar [The desire for a fair budget balance]. C. H. Beck Publishing House.

Bostan, I., \& Grosu V. (2009). Limits on legislative harmonization financial accounting. The 33-rd Annual Congress of the American Romanian Academy of Arts and Sciences (ARA) (pp. 250-253). Politechnic International Press Montreal.

Bostan, I., \& Radu, P. (2003). Controlul financiar și auditul intern la instituțiile publice [Financial control and internal audit in public institutions]. Sedcom Libris.

Bostan, I., Grosu, V., Hlaciuc, E., Mates, D., Burciu, A., Socoliuc, M., Bunget, O., Domil, A., Moraru, M., Peres, C., Petrisor, B., Dumitrescu, A.-C., Artene, A., \& Andronic, B. (2013). The environmental audit (EA) and the environmental balance sheet (EBS) in Romania. J. Food Agric. Environ., 11 (3\&4), 2587-2592. https://www.researchgate.net/publication/293203045 The environmenta 1 audit EA and the environmental balance sheet EBS in Romania

Grosu, V., \& Bostan, I. (2010). IAS/IFRS standards for SMEs and the impact on the Romanian accounting system. International Journal of academic research, 2(4), 284-41. 
Onofrei, M., Cigu, E., Gavriluta, A.-F., Bostan, I., \& Oprea, F. (2021). Effects of the COVID-19 Pandemic on the Budgetary Mechanism Established to Cover Public Health Expenditure. A Case Study of Romania. Int. J. Environ. Res. Public Health, 18, 1134. https://doi.org/10.3390/ijerph18031134

Tinică, G., Bostan, I., \& Grosu, V. (2013). Corelaţii privind creşterea economică şi evoluția costurilor aferente maladiilor cronice. Revista Română de Bioetică, 8(3), 15-24. 